\title{
Effect of nutrients sprays on growth, yield and fruit quality of apple under cold desert condition of Himachal Pradesh
}

\section{K. Sharma}

Department of Horticulture, Chaudhary Sarwan Kumar Himachal Pradesh Agricultural University, Krishi Vigyan Kendra Lahaul \& Spiti at Kukumseri -175142 (Himachal Pradesh), INDIA

E-mail: 1ksharma72@rediffmail.com

Received: June 18, 2015; Revised received: October 16, 2015; Accepted: February 28, 2016

Abstract: The on farm trial was carried out to study the effect of nutrients sprays on growth, yield and fruit quality of apple cv. Royal Delicious under cold desert condition of Himachal Pradesh. Treatments comprised spray of boric acid $(0.1 \%)$, urea $(0.5 \%)$, boric acid $(0.1 \%)+$ urea $(0.5 \%)$, multiplex $(250 \mathrm{ml} / 100$ litre of water) and no use of nutrients (water spray). The highest growth in terms of shoot length was observed with spray of urea at $0.5 \%$ and the highest fruit set and yield were recorded with boric acid $(0.1 \%)+$ urea $(0.5 \%)$ followed by boric acid at $0.1 \%$. The lowest growth, fruit set and yield were observed with control. The combination of boric acid $(0.1 \%)+$ urea $(0.5 \%)$ resulted in the highest fruit length, breadth and weight. The highest total soluble solids were recorded with boric acid $0.1 \%$ and the reducing and total sugars were the highest with control. The acidity was found maximum while total soluble solids, reducing and total sugars were recorded lowest with spray of urea $0.5 \%$. The treatment comprising of boric acid $(0.1 \%)+$ urea $(0.5 \%)$ proved to be best in terms of fruit set, yield and quality parameters of apple followed by boric acid at $0.1 \%$ concentration.

Keywords: Apple, Boric Acid, Multiplex, Quality, Urea, Yield

\section{INTRODUCTION}

Apple (Malus domestica Borkh) is an important member of family Rosaceae and grown widely throughout the world. Most pome fruit orchards need some fertilizer, lime or a trace element to achieve and maintain optimum tree growth and fruit production. Modern pome fruit production calls for greater attention to plant nutrition because of higher density planting, the need for higher fruit production from young plantings, replanting of old orchards due to a shortage of good new land, increased demand for better quality fruit and never-longer storage times (Bright, 2005). Nitrogen is a major element, required by all plants, adequate nitrogen is essential for tree growth, leaf cover, blossom formation, fruit set and fruit size, all of which combine to determine crop yield (Mengel et al, 2001 and Bright, 2005). Nitrogen is required for the initial growth of deciduous trees in the spring during cell division (Ernani and Dias, 1999 and BI et al., 2003). Many workers have shown that fertilization fruit trees with nitrogen fertilizer have been increasing fruit set, vegetative growth and yield (Klein et al., 2006 on Starking Delicious apple trees; Ali et al., 2014 on peach). Boron deficiency is a common trace element disorder of apples. The tree response to foliar application of nutrients may be inconsistent (Weinbaum, 1988). Boron may be applied to the soil or the foliage with good effect. Foliar fertilization has advantage of low application rates, uniform distribution of fertilizer materials, easiest method of application and quick responses to applied nutrients (Khayyat et al., 2007). Application of boron to foliage have a higher increase of fruit set, vegetative growth and yield (Peryea et al., 2003 on apple trees, Usenik and Stampar 2007 on Summit and Hedelfinger of sweet cherry). Nitrogen and boron in addition to soil application appears to have a great effect on growth, yield and quality of fruits. The present studies were therefore, carried out to study the effect of sprays of nutrients (boron, urea and multiplex) on growth, yield and fruit quality of apple.

\section{MATERIALS AND METHODS}

The experiment was conducted at four locations namely Phura, Jhalman, Udaipur and Madgran of Pattan valley in the district Lahaul \& Spiti during 2012 and 2013 on 10 years old Royal Delicious trees raised on seedling rootstock planted at 6x6 m apart. The sites lie at longitude $76^{0} 46^{\prime} 29^{\prime \prime}$ to $78^{0} 41^{\prime} 34^{\prime \prime} \mathrm{E}$, latitude $31^{\circ} 44^{\prime} 57^{\prime \prime}$ to $32^{0} 59^{\prime} 57^{\prime \prime} \mathrm{N}$ and the altitude ranges between 2640 to $2750 \mathrm{~m}$ above sea level. The soils of apple orchard were sandy to sandy loam in texture and neutral to alkaline in reaction and low in fertility. The experimental design in this experiment was randomized block design (RBD) with four replicates for each treatment and three trees per replicate. The treatments comprised $\mathrm{T}_{1}$-spray of boric acid $(0.1 \%), \mathrm{T}_{2^{-}}$urea 
spray $(0.5 \%), \mathrm{T}_{3}$-boric acid $(0.1 \%)+$ urea $(0.5 \%)$ spray, $\mathrm{T}_{4}$-multiplex spray $(250 \mathrm{ml} / 100$ litre of water) and $\mathrm{T}_{5}$ - Control (water foliar application. The sprays of urea and boric acid were done between tight cluster to pink bud stage while multiplex was sprayed after fruit set. The physical characters of the tree and yield were recorded as follows:

Ten shoots were randomly selected around the periphery of the tree and their extension growth was measured before pruning and the results were expressed as $\mathrm{cm}$ shoot $^{-1}$. Fruit set was recorded three weeks after petal fall and per cent fruit set was calculated by following formula given by Westwood (1993).

Fruit set $(\%)=$ Number of fruit set/ Number of flowers cluster $\times 100$

Fruit yield was recorded by removal of crop load during harvesting season as $\mathrm{Kg} /$ tree based on $20 \mathrm{Kg}$ standard apple box and later converted in to $\mathrm{q} / \mathrm{ha}$. The weight of fruit was taken with the help of a top pan balance. The unit sample consisted of ten fruits and the results were expressed as weight in grams per fruit. Fruit diameter was recorded with the help of Vernier caliper. The fruit firmness was measured with the help of Magness and Taylor pressure tester and expressed as $\mathrm{kg} / \mathrm{cm}^{2}$. Total soluble solids were determined using a hand refractometer, percentage of titratable acidity in fruit juice was determined according to AOAC (1995), and total sugar in the fruit pulp was determined by phenol sulphuric method according to (Dubois et al., 1956). Data of both the years were pooled and average mean are given in the Table (1 to 3 ).

\section{RESULTS AND DISCUSSION}

Data clearly were shown that (Table 1) shoot extension growth, fruit set and yield of apple were influenced by using boric acid and urea sprays. Highest shoot exten- sion growth $(20.25 \mathrm{~cm})$ was obtained from application of urea $0.5 \%\left(\mathrm{~T}_{2}\right)$ closely followed by boric acid $0.1 \%$ + urea $0.5 \%\left(\mathrm{~T}_{3}\right)$ and lowest $(15.70 \mathrm{~cm})$ in control $\left(\mathrm{T}_{5}\right)$ treatments as shown in table 1 . Obtained results confirmed that earlier finding of Hansen (1980) who reported that application of urea sprays in spring or autumn to apple trees as a substitute or supplement to soil $\mathrm{N}$ dressing increase the shoot growth. Similarly, Dong et al., (2005) reported the positive relationship between spring growth and the amount of nitrogen reserves for many species and varieties. The highest fruit set $(21.80 \%)$ was recorded with the combination of boric acid $0.1 \%+$ urea $0.5 \%$ sprays $\left(\mathrm{T}_{3}\right)$ which was closely followed by boric acid $0.1 \%(21.00 \%) \quad\left(\mathrm{T}_{1}\right)$ and the lowest fruit set $(15.70 \%)$ were recorded under control $\left(\mathrm{T}_{5}\right)$ treatments. The highest yield (110.64 q/ ha) was recorded with the combination of boric acid $0.1 \%+$ urea $0.5 \%$ sprays $\left(\mathrm{T}_{3}\right)$ which were closely followed by boric acid $0.1 \%(106.42 \mathrm{q} / \mathrm{ha})\left(\mathrm{T}_{1}\right)$, the foliar application of multiplex $(104.76 \mathrm{q} / \mathrm{ha})\left(\mathrm{T}_{4}\right)$ and superior to the rest of treatments including control. Results obtained under study are in line with the findings of Kumar et al. (2003) who reported that foliar application of urea@0.5\% + boric acid $0.1 \%$ resulted in the highest fruit set and yield of Starking Delicious apple. Foliar applications of boron before full bloom or after harvest also increased fruit set and yield of Conference pear (Wojcik and Wojcik, 2003) and apple cultivar Sheikh Amir in Shirvan region of Iran (Asgharzade et al., 2012 ). Boron plays an important role in the pollen germination and elongation of pollen tube growth in deciduous fruits hence resulted in increased fruit set and yield (Roy et al., 2006). Boric acid $(0.1 \%)+$ urea $(0.5 \%)$ sprays resulted in highest fruit weight, length and breadth followed by boric acid $0.1 \%$ and multiplex (Table 2). The important role of B

Table 1. Effect of nutrients sprays on shoot extension growth, fruit set and yield of apple cv. Royal Delicious. Values are of four replicates.

\begin{tabular}{lccc}
\hline Treatment & $\begin{array}{l}\text { Shoot extension } \\
\text { growth }(\mathbf{c m})\end{array}$ & Fruit set (\%) & Yield (q/ha) \\
\hline $\mathrm{T}_{1:}$ Boric acid $(0.1 \%)$ & 18.42 & 21.00 & 106.42 \\
$\mathrm{~T}_{2:}$ Urea $(0.5 \%)$ & 20.25 & 19.50 & 101.35 \\
$\mathrm{~T}_{3:}$ Boric acid $(0.1 \%)+$ Urea $(0.5 \%)$ & 19.60 & 21.80 & 110.64 \\
$\mathrm{~T}_{4}:$ Application of multiplex $(250 \mathrm{ml} / 100 \mathrm{~L}$ water) - 2 spray & 17.05 & 20.30 & 104.76 \\
$\mathrm{~T}_{5}:$ Control (Water foliar application) & 15.70 & 17.75 & 92.80 \\
$\mathrm{CD}_{0.05}$ & 1.12 & 1.20 & 6.40 \\
\hline
\end{tabular}

Table 2. Effect of nutrient sprays on physical fruit quality parameters of apple cv. Royal Delicious. Values are of four replicates.

\begin{tabular}{|c|c|c|c|c|}
\hline Treatment & $\begin{array}{l}\text { Fruit weight } \\
\text { (g) }\end{array}$ & $\begin{array}{l}\text { Fruit length } \\
\text { (cm) }\end{array}$ & $\begin{array}{l}\text { Fruit breadth } \\
(\mathrm{cm})\end{array}$ & $\begin{array}{l}\text { Fruit firmness } \\
\left(\mathrm{kg} / \mathrm{cm}^{2}\right)\end{array}$ \\
\hline $\mathrm{T}_{1:}$ Boric acid & 118.00 & 6.47 & 6.52 & 7.30 \\
\hline $\mathrm{T}_{2:}$ Urea $(0.5 \%)$ & 115.50 & 6.40 & 6.44 & 7.35 \\
\hline $\mathrm{T}_{3:}$ Boric acid $(0.1 \%)+$ Urea $(0.5 \%)$ & 122.20 & 6.54 & 6.62 & 7.37 \\
\hline $\begin{array}{l}\mathrm{T}_{4}: \text { Application of multiplex }(250 \mathrm{ml} / 100 \mathrm{~L} \text { water })-2 \\
\text { spray }\end{array}$ & 117.25 & 6.48 & 6.56 & 7.34 \\
\hline $\mathrm{T}_{5}:$ Control (Water foliar application) & 102.48 & 6.12 & 6.18 & 7.26 \\
\hline $\mathrm{CD}_{0.05}$ & 5.82 & 0.10 & 0.08 & NS \\
\hline
\end{tabular}


Table 3. Effect of nutrient sprays on chemical fruit quality parameters of apple cv. Royal Delicious. Values are of four replicates

\begin{tabular}{|c|c|c|c|c|}
\hline Treatment & $\begin{array}{l}\text { Total soluble solid } \\
\text { (TSS }{ }^{0} \text { B) }\end{array}$ & $\begin{array}{l}\text { Acidity } \\
\text { (\%) }\end{array}$ & $\begin{array}{l}\text { Reducing } \\
\text { sugar }(\%)\end{array}$ & $\begin{array}{l}\text { Total sugar } \\
(\%)\end{array}$ \\
\hline $\mathrm{T}_{1:}$ Boric acid $\quad(0.1 \%)$ & 13.80 & 0.23 & 6.00 & 6.97 \\
\hline $\mathrm{T}_{2:}$ Urea $(0.5 \%)$ & 12.20 & 0.27 & 5.98 & 6.92 \\
\hline $\mathrm{T}_{3:}$ Boric acid $(0.1 \%)+$ Urea $(0.5 \%)$ & 13.68 & 0.21 & 6.21 & 7.02 \\
\hline $\begin{array}{l}\mathrm{T}_{4} \text { : Application of multiplex }(250 \mathrm{ml} / 100 \mathrm{~L} \\
\text { water }) \text { - } 2 \text { spray }\end{array}$ & 12.56 & 0.20 & 6.18 & 7.12 \\
\hline $\mathrm{T}_{5}$ : Control (Water foliar application) & 12.30 & 0.12 & 6.42 & 7.40 \\
\hline $\mathrm{CD}_{0.05}$ & 0.20 & 0.03 & 0.25 & 0.60 \\
\hline
\end{tabular}

in enhancing cell division, cell enlargement building and transporting the organic foods could explain their effects in improving physical fruit quality parameter of apple (Wojcik, et al., 1999) .Nitrogen has been reported to prolong the phase of fruit cell division in apricot which resulted in greater number of cells per fruit resulting in larger fruits (Albrigo et al., 1966). The highest total soluble solids were recorded with boric acid $0.1 \%$ followed by boric acid $0.1 \%+$ urea $0.5 \%$ whereas highest reducing and total sugars were observed with the control and lowest with urea $0.5 \%$ ( Table 3). Fruit acidity was maximum with urea sprays. Urea sprays in general reduced the total soluble solids. According to the results obtained from the research of Amiri et al. (2008) urea foliar application led to decreased fruit quality since it led to rot and decreased soluble solids content of fruit. Also regarding fruit quality as a result of nitrogenous fertilizer application experiment of Nava et al. (2008) indicated negative effect of nitrogenous fertilizer on fruit color, texture firmness and TSS level of apple. Similarly nitrogen has been reported to reduce soluble solids and increase acidity in cherries (Werner, 1978).

\section{Conclusion}

Plant nutrients especially urea and boron play an important role in growth,fruit set, fruit retention and development and cause efficient yield and quality improvement. Our results revealed that spraying apple trees with urea, boric acid and multiplex as individual or in combination (urea and boron) had a positive effect on fruit set, yield and fruit quality. However, it could be concluded that the promising treatment is spraying boric acid $(0.1 \%)$ in combination with urea $(0.5 \%)$ during tight cluster to pink bud stage since it gave the highest values concerning fruit set, yield, and quality parameters of apple.

\section{REFERENCES}

Albrigo, L.G., Claypool, L.L. and Uriu, K. (1966). The effect of nitrogen level on development and maturity of Royal apricots fruits. Proc. Amer. Soc. Hort. Sci., 89: 53-60.

Ali, Amjad, Perveen, Sajida, Shah, Syed Noor Muhammad, Zhang Zengqiang, Wahid, Fazli, Shah Mohib, Bibi, Shahida and Majid, Abdul (2014). Effect of foliar application of micronutrients on fruit quality of Peach. American Journal of Plant Sci., (5) : 1258-1264.

Amiri, M.E., Fallahi, E. and Golchin, A. (2008). Influence of foliar and ground fertilization on yield, fruit quality, and soil, leaf, and fruit mineral nutrients in apple. J. Plant Nut., 31(3): 515-525.

AOAC (1995). Official Methods of Analysis .15 ${ }^{\text {th }}$ Ed. Association of Official Agricultural Chemist, Washington, D.C., USA.

Asgharzade, Ahmad., Valizade ,Gholam Ali and Babaeian, Mahdi (2012) . Investigating the effect of boron spray on yield nutrient content, texture and brix index of apple (Sheikh Amir Variety) in Shirvan region. African Journal of Microbiology Research , 6(11): 2682-2685.

BI, G.; C.F. Scagel; L. Cheng; S. Dong and H. Fuchigami (2003). Spring growth of Almond nursery trees depends upon nitrogen from both plant reserves and spring fertilizer application. J. Hort. Sci. \& Biotech. 78(6): 853 -858 .

Bright, J. (2005). Apple and Pear nutrition. NSW Department of Primary Industries. Primefact 85. pp. 1-12.

Dong, S., Cheng ,L., Seagel C.F. and Fuchigami, L.H. (2005). Timing of urea application affects leaf and root $\mathrm{N}$ uptake in young Fuji/M9 apple trees. J. Hortic. Sci. and Biotech. 80: 116-120.

Dubois M, Gilles, K.A., Homilton J.K., Robers P.A.andSmith, F. (1956). Colorimetric methods for determination of sugar and related substances. Annal. Chem., 28 (3): 350-458.

Ernani, P.R. and Dias, J. (1999). Soil nitrogen application in the spring did not increase apple yield . Ciencia Rural, 59(4): 645- 649 .

Hansen, P. (1980). Yield components and fruit development in Golden Delicious apple as affected by timings of nitrogen supply. Scientia Hortic., 12: 243-257.

Khayyat, M.; E. Tafazoli; S. Eshghi and S. Rajaee (2007). Effect of nitrogen, boron, potassium and zinc sprays on yield and fruit quality of date palm. Am-Euras. J. Agric. and Environ. Sci., 2(3): 289 - 296.

Klein, I., Levin ,I, , Bar-Yosef, B., Assaf , R. and Berkovitz, A. (2006). Drip nitrogen fertigation of Starking Delicious apple trees. Plant and Soil 119(2) : 305- 314.

Kumar, J., Rehalia, A.S., Rana , S.S. and Chandel, J.S. (2003). Effect of pre and post bloom sprays of urea and boric acid on growth, fruit set, yield and fruit quality of apple cv. Starking Delicious. Progressive Horticulture, 35(1): 14-19.

Mengel, K., Kirkby ,E.A. , Kosegarten , H. and Appel, T. (2001). Principles Plant Nutrition. Kluwer Academic publisher Dordrecht.

Nava, G., Dechen, A.R. and Nachtiga, G.R. (2008). Nitrogen and potassium fertilization affect apple fruit quality in Southern Brazil. Commun.Soil Sci. Plant Anal., 39(1-2): 96-107.

Peryea, F.J., Nielsen, D. and Neilsen, G. (2003). Boron maintenance sprays for apple 
: Early season applications and tank- mixing with calcium chloride. Hort Science 38: 542- 546.

Roy, R., N.A., Finck, Blair, G.J. and Tandon , H.L.S. (2006). Plant nutrition for food security. A guide for integrated nutrient management. Food and Agriculture Organization of the United Nations, Rome.

Usenik, V. and Stamper, F. (2007). Effect of late season boron spray on boron accumulation and fruit set of Sumit and Hedelfinger sweet cherry (Prunus avium L.). Acta Agricultura Slovenca, 89 (1) : 51-58.

Weinbaum, S.A. (1988). Foliar nutrition of fruit trees. In: Plant growth and leaf applied chemicals. CRC Press, Inc. Boca Raton, Florida, USA: pp. 81-100.
Werner, H. (1978). Einfluss uterschiedlicher Bodenpflege and N. versorgung auf Frichtgualitatsmer-K male bei Schattenmorelle auf F 12/1, Erwerbstobstbau, 20 : 150153.

Westwood, M.N. (1993). Plant efficiency: Growth and yield measurements. Temperate Zone Pomology. W.H. Freeman and Company (San Francisco) pp. 275-282.

Wojcik, P., Cieslinski, G., and Mika, A. (1999). Apple yield and fruit quality as influenced by boron applications. $J$. Plant Nutrition, 22: 1365-1377.

Wojcik, P. and Wojcik, M. (2003). Effect of boron fertilization on Conference pear tree vigor, nutrition and fruit yield and storability. Plant and Soil . $256: 413$. 